\title{
WING POLLINATION BY BEES IN MEXACANTHUS (ACANTHACEAE)?
}

\author{
J. Per-Henrik Holmqvist ${ }^{1}$, Mariette Manktelow ${ }^{2}$ And Thomas F. Daniel ${ }^{3}$ \\ ${ }^{1}$ Karolinska Institutet, Medical Nobel Institute, Dept. of Cell and Molecular \\ Biology, Molecular Genetics, Nobels väg 3, SE-141 77 Stockholm, Sweden \\ ${ }^{2}$ Dept. of Systematic Botany, Evolutionary Biology Centre, Uppsala University, \\ Norbyv. 18D, SE-752 36 Uppsala, Sweden \\ ${ }^{3}$ Dept. of Botany, California Academy of Science, Golden Gate Park, \\ San Francisco, CA 94118-4599, U.S.A.
}

\begin{abstract}
The monotypic genus Mexacanthus in the Acanthaceae is endemic to west central Mexico where the species M. mcvaughii T.F. Daniel grows. The flower structure is unusual with anthers and stigma positioned laterally, and a nectar barrier opened by force. A pollination study showed that the flowers are mainly visited by fork-tailed emerald Chlorostilbon canivetii (Lesson) and Mexican carpenter bee Xylocopa mexicanorum (Cockerell). Both species manage the nectar barrier and behave as pollinators. The hummingbird transferred pollen by its auricular area. The bee transferred pollen by its wings, which carried numerous pollen grains. Wing pollination is earlier known only from butterfly pollination.
\end{abstract}

Key words: Acanthaceae, Apidae, Hymenoptera, Mexacanthus mcvaughii, wing pollination, Xylocopa mexicanorum.

\section{RESUMEN}

El género monotípico Mexacanthus de la familia Acanthaceae es endémico del centro occidente de México, donde está representado por la especie M. mcvaughii T.F. Daniel. La estructura de la flor es poco usual, con las anteras y el estigma en posición lateral y una barrera de néctar que no se abre sin el ejercicio de fuerza. El estudio de la polinización muestra que las flores son visitadas principalmente por el colibrí tijereta esmeralda Chlorostilbon canivetii (Lesson) y por el abejorro Xylocopa mexicanorum (Cockerell). Ambas especies abren sin problemas la barrera de néctar y se comportan como polinizadores. Los colibríes transfieren el polen en su área auricular; la abeja lo hace en sus alas, en las cuales lleva numerosos granos. La polinización por alas anteriormente se conocía sólo de lo registrado en representantes del grupo de las mariposas.

Palabras clave: Acanthaceae, Apidae, Hymenoptera, Mexacanthus mcvaughii, polinización por alas, Xylocopa mexicanorum. 
When an insect visits a flower, pollen is generally deposited onto either its hairy head, proboscis, thorax or abdomen. More rarely, floral adaptations may result in pollen being deposited onto the wings (pterotriby; L. Anders Nilsson, pers. com.), with subsequent pollination of the flower. This has been reported in Gloriosa superba L. (Hingston, 1930) and Caesalpinia pulcherrima (L.) Sw. (Cruden \& Hermann-Parker, 1979), both pollinated by butterflies. Hitherto, wing pollination is known only from butterflies (Lepidoptera). However, in a preliminary study of the pollination biology of Mexacanthus mcvaughii T.F. Daniel (Acanthaceae), indications of wing pollination by a carpenter bee, Xylocopa mexicanorum (Cockerell), were found.

Mexacanthus (Acanthaceae) is a monotypic genus (Daniel, 1981) from Colima and Jalisco in west-central Mexico, where the only species M. mcvaughii grows on slopes and along washes in dry forest. Many of its floral features are peculiar in comparison to closely related genera, e.g., Anisacanthus. The species of Anisacanthus all have reddish, long-tubed corollas (Fig. 1A) typical of birdpollinated flowers (Faegri \& van der Pijl, 1979), but M. mcvaughii (Fig. 1B) has a corolla with traits suggesting a more generalized pollination system that also involves insects (cf. Johnson \& Steiner, 2000). The sympetalous and zygomorphic corolla in Mexacanthus is mainly yellow. Only the narrow, reflexed upper lip is dull red. The corolla tube is fairly short $(3.5-5.0 \mathrm{~mm})$ relative to the lips $(13-19 \mathrm{~mm})$. The strongly reflexed lower lip is apically split into lobes, but the base of the lip is undivided and may serve as a landing platform (Fig. 1C). The stamens protrude to each side forming an angle of approximately 60 degrees. The filaments are partly fused with the corolla wall. However, they are not fastened inside the corolla tube, which is common in Acanthaceae, but onto the lower, outer corolla lobes. The style is slightly longer than the stamens, and is directed more or less parallel to either one of the filaments, but slightly below. A unique feature in Mexacanthus compared to related genera is the pollen being two-aperturate rather than three-aperturate. A transverse nectar barrier is located at the mouth of the tube (Holmqvist, 2000). The style may be pushed downwards into a slit in the barrier, leaving a circular opening to the nectar chamber. A homologous barrier has been found in Anisacanthus (Manktelow, 1998, Holmqvist, 2000), where it is believed to be an adaptation to bird pollination by excluding other visitors from the nectar. The bird presumably has to push the style from the top to the bottom of the barrier with its beak to reach the nectar (Mariette Manktelow \& Per-Henrik Holmqvist pers. obs.).

Hummingbirds have been observed as frequent visitors of $M$. mcvaughii (Thomas F. Daniel, pers. obs.), as may be predicted by some characters of the species, including the protruding anthers, the placement of the flowers along leafless flexible branches, the lack of odor, the nectar barrier, and the red and yellow color of the corolla (cf. Grant \& Grant, 1968; Fægri \& van der Pij1, 1979; Endress, 1994). 

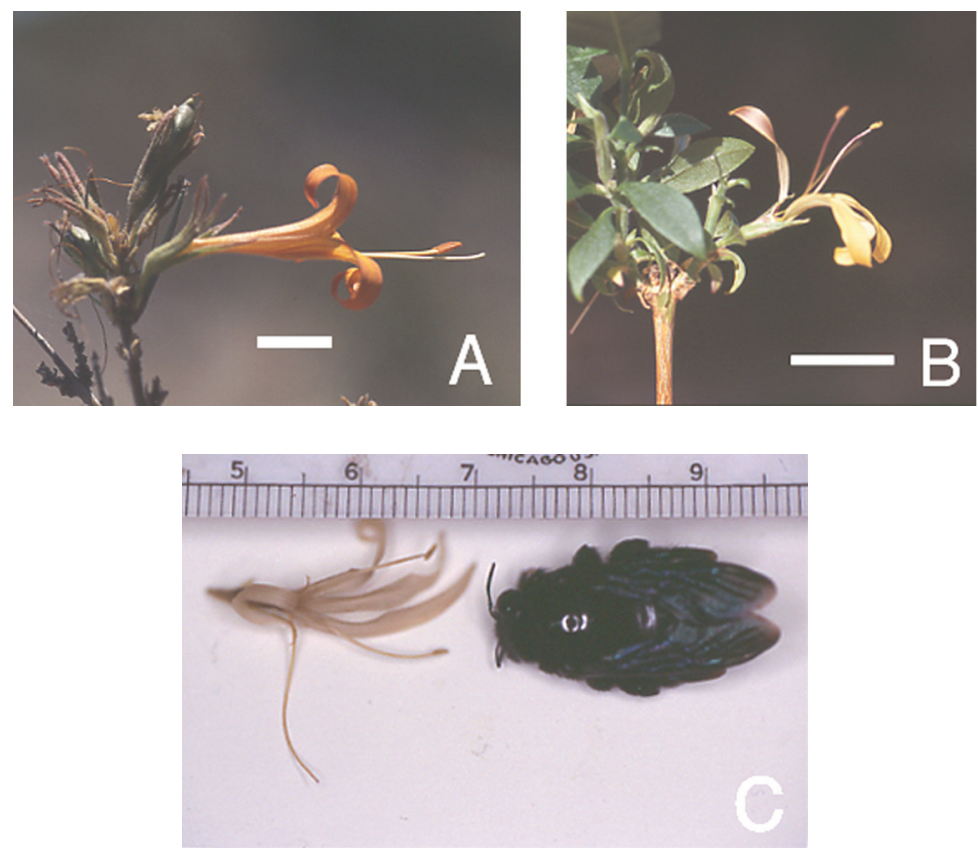

Fig. 1. Comparison of the flowers of (A) Anisacanthus thurberi and (B) Mexacanthus mcvaughii (bar in both figures $1 \mathrm{~cm}$ ); (C) Picture of Xylocopa mexicanorum with a pickled flower of Mexacanthus mcvaughii. Photographs by Mariette Manktelow (A), Stephen Manktelow (B) and Per-Henrik Holmqvist (C).

However, the yellow corolla parts, the landing platform and the short tube suggest involvement of a nectar-feeding insect pollinator. Such a pollinator must: 1) be able to get through the nectar barrier, and 2) have contact with the anthers and stigma such that deposition of pollen may take place.

The field studies were carried out from March 22 to March 25, 1999, near the end of the dry season in Arroyo de Colorado, near Chamela, Jalisco, Mexico $\left(19^{\circ} 30^{\prime} 57^{\prime \prime} \mathrm{N} ; 105^{\circ} 02^{\prime} 33^{\prime \prime} \mathrm{W} ; 20 \mathrm{~m}\right.$ elev.). A total of seven shrubs were included in the study, one of which was observed during the visitor frequency study. Eight species of floral visitors were observed during daylight hours, and no visitors were detected at night. A visitor frequency study was carried out for eight daylight hours at different times during the day.

Five visitors were infrequent and behaved as nectar thieves or robbers (sensu Inouye, 1980): the butterflies Eurema boisduvaliana (Felder \& Felder), Heliopetes sp., Pontia protodice (Boisduval \& LeConte), the stingless bee Trigona fluiventris Guérim, and a bombylid fly of the subfamily Exoprosopinae. Three visitors were 
frequent: Apis mellifera L. (common honeybee), which acted as a pollen thief and did not contribute to the pollination, Chlorostilbon canivetii (Lesson) (fork-tailed emerald) and Xylocopa mexicanorum (Mexican carpenter bee), which both behaved as legitimate visitors and potential pollinators.

Chlorostilbon canivetii visited each flower for one to two seconds, and inserted its beak into the corolla tube while hovering. It thereby touched the anthers and stigma with its auricular area (the sides of its head). To reach the nectar it seemed to push the style downwards with its beak. The bird made 2.4 visits/hour/ shrub, and visited several flowers of the same shrub in a period of one to two minutes. A total of 19 visits to all shrubs by the hummingbird were recorded during the field study.

Xylocopa mexicanorum landed on the platform of the lower lip after a short time of hovering in front of the flower. The bee landed on the style and inserted its proboscis into the nectar chamber above the style. It took nectar for approximately one second. The only part of the bee in contact with the anthers and stigma were the lateral parts including the wings. Xylocopa mexicanorum made 3.3 visits/hour/shrub, and visited around 20 (i.e., almost all) flowers on the observed shrub systematically during a period of two to five minutes. A total of 32 visits to the shrubs by $X$. mexicanorum were noted during the field study. All carpenter bees behaved in the same way.

A preliminary phenology study of ten flowers distributed on five shrubs of M. mcvanghii showed that 50 percent of the flowers opened around sunrise, and the rest at different times between 10.00 and 14.00. Most corollas remained on the plant less than 24 hours, before dehiscing. The number of simultaneously open flowers was low, resulting in a prolonged flowering period for each individual shrub as well as for each branch. Analyses of nectar sugar composition in two flowers of a cultivated individual of M. mcvaughii (Daniel 2107gh) have revealed sucrosedominated nectars with sucrose/hexose ratios of 4.7 and 2.4 (ave. $=3.55$; Thomas F. Daniel \& C. Edward Freeman, pers. obs.). Greenhouse studies have revealed that M. mcvaughii is self-compatible but not autogamous (Thomas F. Daniel, pers. obs.).

Pollination by both the hummingbird $C$. canivetii and the carpenter bee $X$. mexicanorum in $M$. mcvaughii is congruent with the flowers opening mainly in the morning (when these two animals were active, and exclusive visitors), the prolonged flowering period of each individual shrub (Janzen 1971), the nectar barrier opened by force alone (van der Pijl, 1954; Hedström \& Thulin, 1986; Westerkamp, 1993; Endress, 1994; Mariette Manktelow \& Per-Henrik Holmqvist pers. obs.), and the high proportion of sucrose relative to hexose sugars in the nectar. The latter is typical of hummingbird-flowers (Baker \& Baker, 1983; Freeman et al., 1984; Stiles \& Freeman, 1993), but occurs also in species adapted to pollination by Xylocopa, e.g., 
Brillantaisia spp. (Acanthaceae) (Troll, 1951; Kullenberg, 1955; Schwerdtfeger, 1996; Manktelow, 2000).

Xylocopa mexicanorum fulfills the above criteria for a nectar-taking insect pollinator in M. mcvaughii. The weight of the bee when landing upon the style should be enough to open the nectar barrier (i.e., to push the style downwards into the slit in the nectar barrier). No destruction of the barrier, suggesting piercing by the bee, was seen on the flowers after a visit. The morphological match between $X$. mexicanorum and the Mexacanthus flower predicted pollen deposition on the lateral parts of the insect (Fig. 1C). The maximum width of the captured bee was $12 \mathrm{~mm}$, while the average distance between the anthers was $15 \mathrm{~mm}$. A bee that had visited half of the flowers in sequence (around 10) on one shrub was captured and examined.

Numerous pollen grains of $M$. mcvaughii were found predominantly on the surfaces of the wings (Fig. 2), as well as within the "curled" hamuli (hook-like hairs keeping the two sidewings together during flight) of each hind wing, but not on other parts of its body. As the wings are unhooked by a circular movement at landing, they apparently also brush the sexual parts of M. mcvaughii.
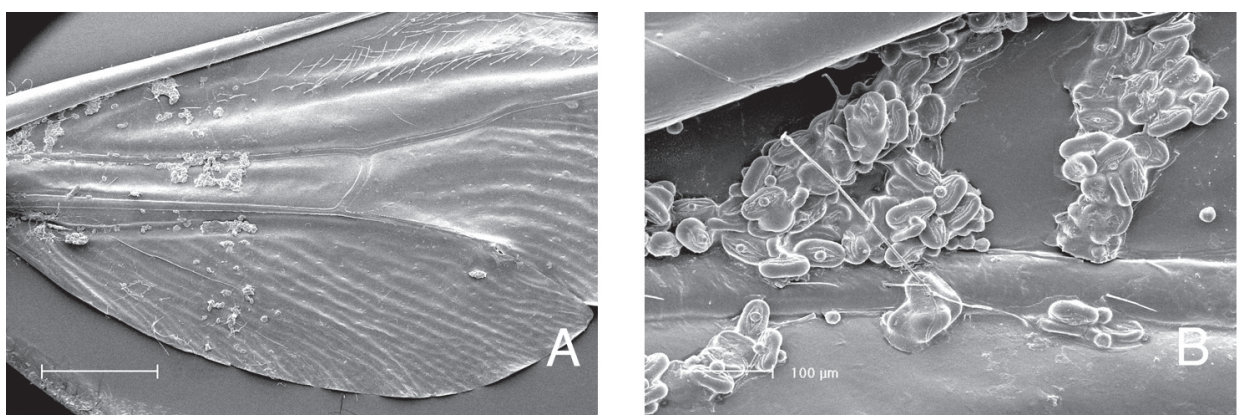

Fig. 2. Pollen from Mexacanthus mcvaughii on the wings of Xylocopa mexicanorum. (A) lower surface of hindwing with pollen; (B) detail of wing showing pollen of Mexacanthus mcvaughii. SEM Photograph by Gary Wife.

We conclude that wing pollination by bees may occur in Mexacanthus. This needs to be confirmed by subsequent studies. These should include prolonged visitor frequency and behaviour studies, a detailed study of the capture and stigma deposition of pollen by the wings, and an evaluation of the relative effectiveness of Xylocopa pollination.

We are grateful to Felipe Noguera, Alicia Rodríguez Palafox, Raymundo Ramírez and his students, the staff at Estación de Biología de Chamela, and Nils 
Ryrholm for help in the field and taxonomic assistance. Our thanks are extended to Lucinda McDade, Margrit Mcintosh, Sara Richardson and Michelle Zjhra for shared facilities and fruitful discussions, and also to L. Anders Nilsson, Kim Steiner and our reviewers for valuable comments on the manuscript. We thank Gary Wife for SEM photography and Stephen Manktelow for field photography. The study is part of a project supported by grants to M. Manktelow by the Fulbright Commission, Helge Ax:son Johnson's Foundation, Helmuth Hertz Foundation, Knut and Alice Wallenberg's Foundation, Research Training Group at the University of Arizona, and Wahlberg's foundation; to J. P. H. Holmqvist through a grant from Embleton Sundberg foundation.

\section{LITERATURE CITED}

Baker, H. G. \& I. Baker. 1983. Floral nectar sugar constituents in relation to pollinator. In: C. E. Jones and R. J. Little (eds.). Handbook of Experimental Pollination Biology. Van Nostrand Reinhold. New York. pp. 117-141.

Cruden, R. W. \& S. M. Hermann-Parker. 1979. Butterfly pollination of Caesalpinia pulcherrima, with observations on a psychophilous syndrome. Journal of Ecology 67: 155-168.

Daniel, T. F. 1981. Mexacanthus, a new genus of Acanthaceae from western Mexico. Systematic Botany 6: 288-293.

Endress, P. K. 1994. Diversity and evolutionary biology of tropical flowers. Cambridge University Press. Cambridge. 511 pp.

Fægri, K. \& L. van der Pijl. 1979. The principles of pollination biology. Pergamon Press. Oxford. $244 \mathrm{pp}$.

Freeman, C. E., W. H. Reid, J. E. Becvar \& R. Scogin. 1984. Similarity and apparent convergence in the nectar-sugar composition of some hummingbird-pollinated flowers. Botanical Gazette 145(1): 132-135.

Grant, K. A. \& V. Grant. 1968. Hummingbirds and their flowers. Columbia University Press. New York and London. 115 pp.

Hedström, I. \& M. Thulin. 1986. Pollination by a hugging mechanism in Vigna vexillata (Leguminosae-Papilionideae). Plant Systematics and Evolution 154: 275-283.

Hingston, R. W. G. 1930. Pollen on the wings of Papilio butterflies. Proceedings of the Royal Entomological Society of London, Ser. A 5: 114-117.

Holmqvist, J. P. H. 2000. Study of pollination-biology strategies adapted by two closely related species within the Acanthaceae in an evolutionary context. Masters thesis in Biology. Uppsala University. Uppsala. 52 pp.

Inouye, D. W. 1980. The terminology of floral larceny. Ecology 61(5): 1251-1253.

Janzen, D. 1971. Euglossine bees as long-distance pollinators of tropical plants. Science 171:203-205. 
Johnson, S. D. \& K. E. Steiner. 2000. Generalization versus specialization in plant pollination systems. Trends in Ecology and Evolution 15(4): 140-143.

Kullenberg, B. 1955. Quelques observations sur les Apides en Côte-d'Ivoire faites en août 1954. Bulletin de l'Institut Français d'Afrique Noire. Série A 17A(4): 1125-1131.

Manktelow, M. 1998. How to economize nectar in a broiling hot desert-pollination biology of Anisacanthus thurberi (Acanthaceae). 1998 Meeting of the Southwestern Association of Biologists. Abstracts. Portal, Arizona.

Manktelow, M. 2000. The filament curtain: a structure important to systematics and pollination biology in the Acanthaceae. Botanical Journal of the Linnean Society 133: $129-160$.

Schwerdtfeger, M. 1996. Die Nektarzusammensetzung der Asteridae und ihre Beziehung zu Blütenökologie und Systematik. Dissertationes Botanicae 264.

Stiles, F. G. \& C. E. Freeman. 1993. Patterns in floral nectar characteristics of some birdvisited plant species from Costa Rica. Biotropica 25: 191-205.

Troll, W. 1951. Botanische Notizen II. Akademie der Wissenschaften und der Literatur, Mainz. Abhandlungen der matematisch-naturwissenschaftlichen Klasse 2: 21-80.

van der Pijl, L. 1954. Xylocopa and flowers in the tropics I. Proceedings, Koninklijke Nederlandse Akademie van Wetenschappen, Series C, Biological and Medical Sciences 57(3): 413-423.

Westerkamp, C. 1993. The co-operation between the assymetric flower of Lathyrus latifolius (Fabaceae-Vicieae) and its visitors. Phyton 33(1): 121-137. 
